\title{
Upper Eocene and Oligocene Larger Foraminifera From Viti Levu, Fiji
}

GEOLOGICAL SURVEY PROFESSIONAL PAPER 374-A 


\section{Upper Eocene and Oligocene}

Larger Foraminifera From Viti Levu, Fiji

By W. STORRS COLE

SHORTER CONTRIBUTIONS TO GENERAL GEOLOGY

GEOLOGICAL SURVEY PROFESIONAL PAPER 374-A

Illustrations of first Eocene and Oligocene fossils

from Fiji, and their occurrence in

surrounding areas

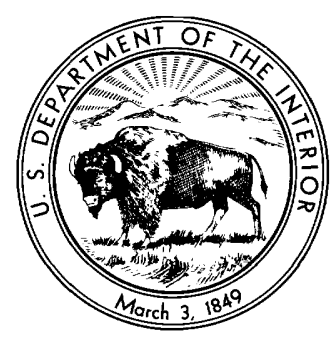

UNITED STATES GOVERNMENT PRINTING OFFICE, WASHINGTON : 1960 


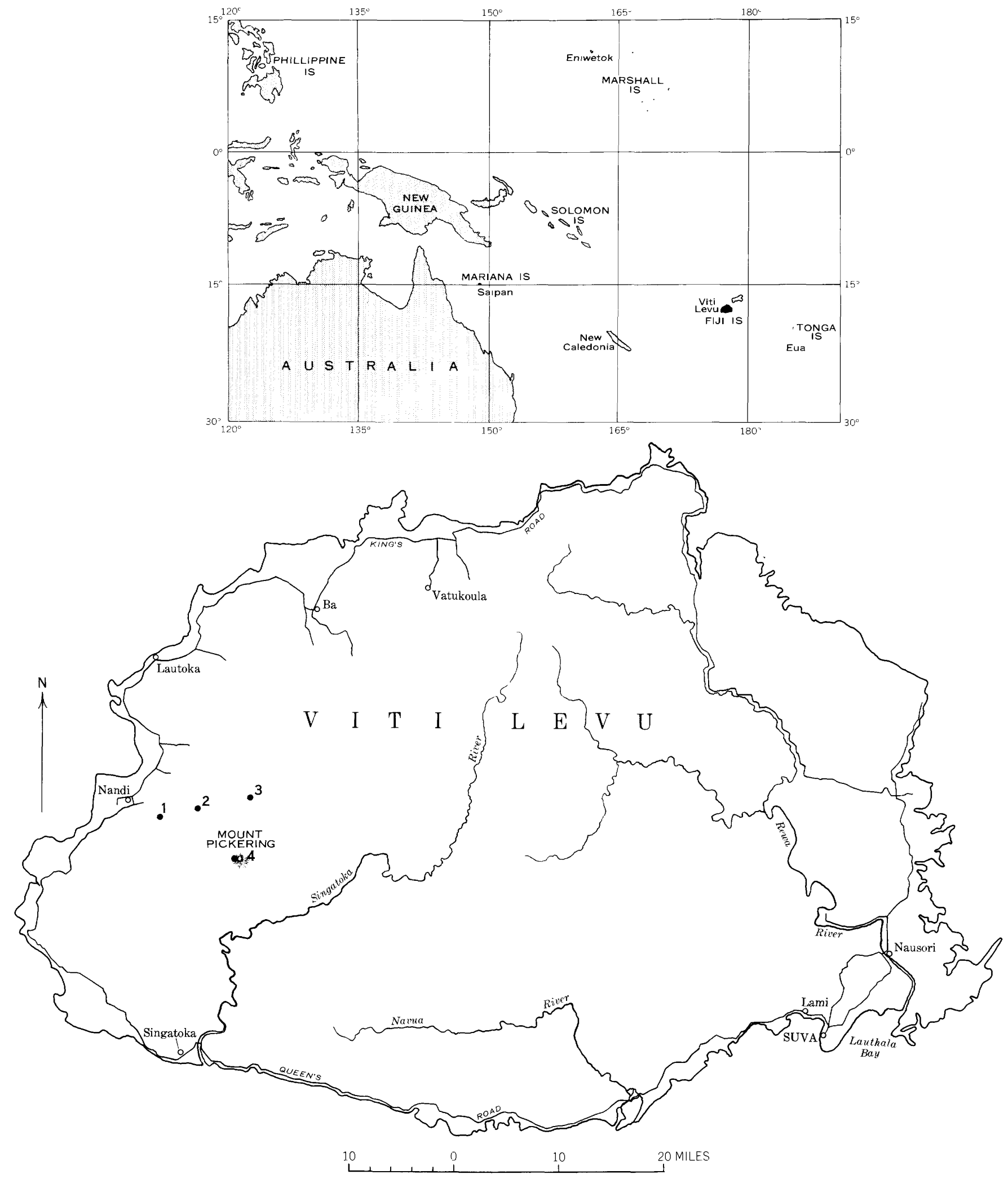

Figure 1. Locality and index map. 
TABLE 1.-Distribution of larger Foraminifera in the upper Eocene samples from Viti Levu, Fiji and elsewhere

$[\mathrm{r}=$ rare; $\mathrm{c}=$ common; $\mathrm{a}=$ abundant; $\mathrm{X}=$ present $]$

\begin{tabular}{|c|c|c|c|c|c|c|c|}
\hline & Loc. 1 & Loc. 2 & Loc. 3 & Saipan & $\begin{array}{l}\text { Eniwetok } \\
\text { drill } \\
\text { holes }\end{array}$ & $\begin{array}{l}\text { Eua, } \\
\text { Tonga }\end{array}$ & Indonesia \\
\hline Camerina pengaronensis (Verbeek) & $\mathrm{r}$ & & $\ldots$ & $\times$ & $x$ & $x$ & $\times$ \\
\hline Operculina saipanensis (Cole) $\ldots$ & & -- & $\mathbf{r}$ & $x$ & $\times$ & & \\
\hline Spiroclypeus vermicularis Tan $\ldots$ & $\mathrm{c}$ & a & $-\ldots$ & $x$ & $\times$ & & $x$ \\
\hline fulgeria (Whipple) & $\mathrm{c}$ & $\ldots \ldots$ & $-\ldots \ldots$ & $x$ & $x$ & $x$ & $x$ \\
\hline Discocyclina (Discocyclina) omphala (Fritsch) $\ldots . . . . . .$. & -- & $-\ldots-1-1$ & a & $\times$ & & $x$ & $x$ \\
\hline Asterocyclina matanzensis Cole & $\mathrm{c}$ & $\mathrm{c}$ & c & $\times$ & $x$ & $x$ & x \\
\hline
\end{tabular}

As these species are widespread in Tertiary $b$ (upper Eocene) of Indonesia and the islands of the central Pacific, the deposits in which they occur on Viti Levu, Fiji, are assigned to this letter stage.

Whipple (1932, in Hoffmeister, p. 79) described several species from the Tertiary $b$ (upper Eocene) of Eua, Tonga. Certain of these species were identified incorrectly and others were inadequately described. A revised list of certain of these species follows:

Names used by Whipple

Camerina pengaronensis (Verbeek)

Pellatispira fulgeria Whipple

Discocyclina (Discocyclina) fritschi (H. Douvillé) euaensis Whipple

(Asterocyclina) stellata (d'Archiac)

This fauna is similar to the one at locality 1 on Viti Levu, Fiji.

Although all the species do not occur together in the three samples from Viti Levu, they do occur together elsewhere. Therefore, their distribution in the samples from Viti Levu may be ascribed either to inadequate size of the samples, or, more probably, to slight ecological controls.

\section{OLIGOCENE FAUNA}

It was possible to identify only two species with certainty from the one Tertiary $c$ (Oligocene) locality. These are Camerina fichteli (Michelotti) and Gypsina discus Goës. There were numerous small specimens of Heterostegina in association with these two species, but unfortunately the sections were not sufficiently centered for specific identification.

Tertiary $c$ in Indonesia is characterized by the disappearance of the restricted Eocene genera, the presence of the reticulate species Camerina fichteli and the absence of Lepidocyclina (Eulepidina) which appears first in this area in Tertiary $d$.
Van der Vlerk $(1929$, p. 7$)$ assigned to Tertiary $c$ several localities in northeast Borneo at which he found Camerina fichteli and a heterostegine which he identified as $H$. reticulata Rütimeyer. Bursch (1947, table 1) reported $C$. fichteli and Gypsina discus in association at several localities on Gross Kei, Moluccan Islands, in sediments which he assigned to Tertiary $c$.

$C$. fichteli has been reported from Tertiary $c$ beds in Java (Doornink, 1932, p. 285), Borneo (H. Douvillé,

Names used in this report

C. pengaronensis (Verbeek)

Biplanispira fulgeria (Whipple)

D. (D.) omphala (Fritsch)

D. (D.) omphala (Fritsch)

A. matanzensis Cole

1905 , p. 454), Soemba (Caudri, 1934, p. 72) as well as other localities in Indonesia. Cole (ms. in preparation) found this species in the Tertiary $c$ of Guam. This occurrence on Guam represents the most eastern penetration of this species into the Pacific basin so far recorded.

\section{PALEOECOLOGY}

The specimens from locality 1 are embedded in pyroclastic material through which they are distributed more or less uniformly, but with the individual specimens commonly surrounded by matrix. This material is in marked contrast to that from locality 2 which represents a foraminiferal coquina (pl. 1, fig. 1). The individual specimens are often in contact and where spaces intervene between the specimens they are filled with broken fragments of foraminiferal tests. The abundant specimens from locality 3 are Discocyclina (Discocyclina) omphala (Fritsch) which commonly are arranged parallel to each other and generally separated by a thin zone of matrix composed mainly of 
small broken fragments of calcareous algae and other organic debris.

The best estimate for depth of accumulation of sediments of this type would be 25-40 fathoms in waters with temperatures between $22^{\circ} \mathrm{C}$ and $27^{\circ} \mathrm{C}$.

Spiroclypeus is structurally similar to Heterostegina. a genus still living. Cushman, Todd and Post (1954. p. 320) in discussing the foraminiferal faunas of the lagoons of Rongerik, Rongelap, Bikini and Eniwetok stated-

Next in abundance in the lagoons is Heterostegina suborbicularis d'Orbiguy, which in a few places is more abundant than Amphistegina.

The fauna from locality 2, dominated by spirnclypeus vermicularis Tan, seemingly existed under conditions somewhat similar to those found at present in the lagoons of atolls.

The sediments in which Discocyclina (Discocyclina) omphala (Fritsch) occur at locality 3 seemingly accumulated in water which was sufficiently deep so that the Discocyclina were not disturbed by wave or current action, but into which gentle currents were able to transport organic debris originating in shallower water.

\section{SYSTEMATIC DESCRIPTIONS}

\section{Family CAMERINIDAE}

Genus CAMERINA Bruguière, 1792

Camerina fichteli (Michelotti)

Plate 3, figures 5, 9-18

1841. Nummutites fichteli Michelotti, Soc. Ital. Sci., Mem., v. 22 , p. 296 , pl. 3 , fig. 7 .

1934. Camerina fichteli (Michelotti). Caudri, Tertiary Deposits of Soemba, Amsterdam, p. 72-81 (references).

1947. Nummulites intermedius-fichteli d'Archiac and Michelotti 1846, 1841. Bursch. Schweizerische Palaeont. Gesell., Abhand.. v. 65, p. 19-21, pl. 1, figs. 4-6, 26 ; pl. 2, figs. 6, 7 ; pl. 5 , fig. 5 (references and syuonyms).

This species is a reticulate camerinid. The reticulate pattern shows in the external view of shightly weathered specimens and in median sections which are not centered (see: fig. 11, pl. 3). The transverse sections superficially resemble those of Spiroctypeus.

Discussion.-Numerous specimens of this species were found on Guam. Although these specimens were associated at certain localities on Guam with characteristic Tertiary $b$ (upper Eocene) genera and species (Cloud and Cole, 1953, p. 323), later detailed mapping and studies of the faunas has demonstrated that the Tertiary $b$ specimens represented reworked material (Cole, ms. in preparation). Therefore, the range of $C$. fichteli does not extend downward into Tertiary $b$ as Cloud and Cole suggested it might to explain the association they found on Guam.

\section{Camerina pengaronensis (Verbeek)}

Plate 2, figure 4

1958. Camerina pengaronensis (Verbeek). Cole, I.S. Geol. Survey Prof. Paper 260-V, p. 753, 754, pl. 231, figs. 1-17 ${ }^{1}$

[imprint date, 1957; references and synonyms]

This species occurred infrequently in the thin sections from locality 1 . The best transverse section observed is figured.

\section{Genus Operculina d’Orbigny, 1826}

For a review of the synonyms of Operculina see: Cole, 1959 , p. 351.

Operculina saipanensis (Cole)

1958. Operculinoides saipanensis Cole. Cole, I.S. Geol. Survey Prof. Paper 260-V, p. 755. pl. 232, figs. 7-14; pl. 233. figs. 31, 32 [impriut date, 1957; references].

The identification of this species which occurred infrequently in the thin sections from locality 3 is based on several complete and well-oriented transverse sections and one oblique median section.

\section{Genus HETEROSTEGINA d'Orbigny, 1826}

\section{Heterostegina sp.}

Plate 3, figures 1, 2, 6, 8

As a well oriented median section was not found, it is impossible to identify this species. Two transverse and two median sections are illustrated for future reference.

Discussion.-Specimens of Heterostegina in the Tertiary $c$ of Borneo found in association with Camerina fichteli have been identified by van der Vlerk (1929, p. 16) as $H$. reticulata Rüimeyer, the types of which are from the Eocene of Switzerland. Tan (1932, p. 136) referred other Indonesian specimens of Heterostegina to Heterostegina cf. $H$. depressa d'Orbigny.

The details which could be observed suggest that these specimens are close to $H$. duplicamera Cole, a species described from lower Tertiary e (Miocene) sediments encountered in the Eniwetok drill holes.

\section{Genus SPIROCLYPEUS H. Douvillé, 1905}

Spiroclypeus vermicularis Tan

Plate 1, figures $10-14$

1958. Spiroclypeus vermicularis Tan. Cole, U.S. Geol. Survey Prof. Paper 260-V, p. 764 , pl. 238, figs. 1-6, 8-10, 11, 12 [imprint date, 1957].

Discussion.-The types are from Tertiary $b$ deposits at Koetai, East Borneo. Typical specimens were

1 This report, which carries a 1957 imprint, was widely distributed in February 1958. It was not accepted officially by the Geological Survey until copies with improved collotype plates were received in March 1959. 
found on Saipan and in Eniwetok drill hole F-1. In this drill hole they occur in core 11 at a depth of 4197 4222 feet (Cole, 1958, p. 749).

This typical Indo-Pacific genus is known to occur in the Indo-Pacific region only in Tertiary $b$ and Tertiary $e$ sediments. Although several species have been described from Tertiary $e$ localities, the only species reported from the Tertiary $b$ stage is $S$. vermicularis.

\section{Genus PELLATISPIRA Boussac, 1906}

\section{Pellatispira provaleae Yabe}

Plate 1, figure 3

1957. Pellatispira proralcae Yabe. Cole, U.S. Geol. Survey Prof. Paper 280-I, p. 333, pl. 96, figs. 1. 2. 6 ; pl. 98, figs. 1-12.

This species was represented by two incomplete sections in the thin sections from locality 2 . The best section is illustrated.

\section{Genus BIPLANISPIRA Umbgrove, 1937 \\ Biplanispira fulgeria (Whipple)}

Plate 1. figure 2 ; plate 2 , figure 3

1958. Biplanispira fulgeria (Whipple). Cole. U.S. Geol. Survey Prof. Paper $260-V$, p. 765 [imprint date, 1957 ; references and synonyms].

This species was represented by numerous partial sections in the thin sections from locality 1 . The expanded marginal cord is a distinctive and easily recognized feature of this species.

\section{Biplanispira mirabilis (Umbgrove)}

1958. Biplanispira mirabilis (Umbgrove). Cole, U.S. Geol. Survey Prof. Paper $260-$ V, p. 765 [imprint date, 1957 ; references and s.ynonyms].

A few specimens were found at locality 1 in association with Biplanispira fulgeria. These two species normally occur together.

\section{Family RUPERTIIDAE \\ Genus GYPSINA Carter, 1877 \\ Gypsina discus Goës}

Plate 3 , figures $3,4,7$

1947. Gypsina discus Goës. Bursch, Schweizerische Palaeont. Gesell., Abhand., v. 65, p. 40-12, pl. 3, figs. 2, 4, 13, 17, 22 ; pl. 5, figs. 6, 7 ; text figs. 15, 20 (references).

Discussion.-The specimens are identical with those which Bursch described in detail from Gross Kei, Moluccan Islands. He identified this species both in Tertiary $b$ (upper Eocene) and Tertiary $c$ (Oligocene) beds. The type of the species is from the Caribbean sea, dredged from a depth of 400 fathoms.

The embryonic and equatorial chambers (fig. 4, pl. 3) should be compared with the diagram given by
Bursch (1947, p. 41, text fig. 20$)$ and the vertical section (fig. 7, pl. 3) should be compared with his schematic diagram (Bursch, 1947, p. 35, text fig. 15C).

\section{Family DISCOCYCLINIDAE \\ Genus DISCOCYCLINA Gümbel, 1870 \\ Subgenus DISCOCYCLINA Gümbel, 1870 \\ Discocyclina (Discocyclina) omphala (Fritsch)}

Plate 2, figures 1, 2, 5-11

19.7. Discocyclina (Discocyclina) omphala (Frits(h). Cole, U.S. Geol. Survey Prof. Paper 280-I, p. 347-349, pl. 115, figs. 1-12 [references and synonyms].

1957. Discoryclina (Discocyclina) indopacifica Hanzawa, Geol. Soc. America, Mem. 66, p. 82, 83, pl. 12, figs. 1, 2: pl. 13, figs. 2, 5, 6 .

The part of the vertical section (pl. 2, fig. 7) should be compared with a similar section (Cole, 1957, pl. 115, fig. 10) of a specimen from Saipan. The internal structures are identical.

Specimens identified as this species by H. Douvillé (1905, p. 440, text figs. 1, 2) have a marked depressed area within the central umbo. Certain specimens from Saipan (see Cole, 1957, pl. 115, figs. 3, 4, 10) exhibit this same pattern. Other specimens, however, have an inflated umbo (Cole, 1957, pl. 115, figs. 6, 7). A few specimens from Viti Levu, Fiji (pl. 2, figs. 6, 7 ) have the depressed area within the central umbo, but the majority of the specimens are similar to the one illustrated as figure 5, plate 2 .

As previously mentioned-

External shape is not a criterion upon which a species may be based as this character is variable. Internal structure is constant, and the main reliance for the definition of species of larger Foraminifera should be based on the internal structure (Cole, 1957, p. 349).

Discussion.-Although several species of Discocyclina have been described from Indonesia, they are imperfectly known because of inadequate descriptions and illustrations. One of the species reported from numerous localities is $D$. javana (Verbeek). Caudri (1934, p. 87) wrote-

Judging from the number of Discocyclina javana Verbeek recorded from all parts of the Archipelago, one would be inclined to think that this Discocyclina was an easily determinable species. Nothing is further from the truth.

D. javana has been reported from numerous localities in Indonesia associated with specimens identified as D. omphala and D. dispansa (Sowerby). Study of the literature as well as certain Indonesian specimens from the Vaughan collection in the U.S. National Museum suggests that all of these Indonesian specimens represent only one species.

D. dispansa was described from specimens obtained in India. Therefore, it is doubtful if the Indonesian 
$[\quad-\ldots$ 


\section{PLATES 1-3}




\section{PLATE 1}

Figure 1. A part of a thin section of the foraminiferal coquina from locality 2 to show the abundance of the tests; specimens on the left side are Spiroclypeus vermicularis Tan suld the large specimen on the right side is Asterocyclina matanzensis Cole. USNM 627576.

2. Biplanispira fulgeria (Whipple) (p. A-5)

Oblique section through the embryonic chambers; locality 1. USNM 627577.

3. Pellatispira provaleae Yabe (p. A-5)

Oblique transverse section (see: Cole, $1957, \mathrm{pl}, 98$, fig. 12); locality 2 . USNM 627578.

4-9. Asterocylina matanzensis Cole (p. A-6)

4. Vertical section, centered; locality 2. USNM 627579.

5. Vertical section, not centered, along the rays; locality 1 . USNM 627580

6,7 . Vertical sections, not centered; locality 1 . USNM 627581 .

8. Slightly oblique equatorial section of a megalospheric individual; locality 2 . USNM 627582.

9. Oblique equatorial section to show the equatorial chambers; locality 2 . USNM 627583.

10-14. Spiroclypeus vermicularis Tan (p. A-4)

10, 11. Median sections; locality 2 . USNM 627584.

12, 13, 14. Transverse sections; locality 2 . USNM 627585. 


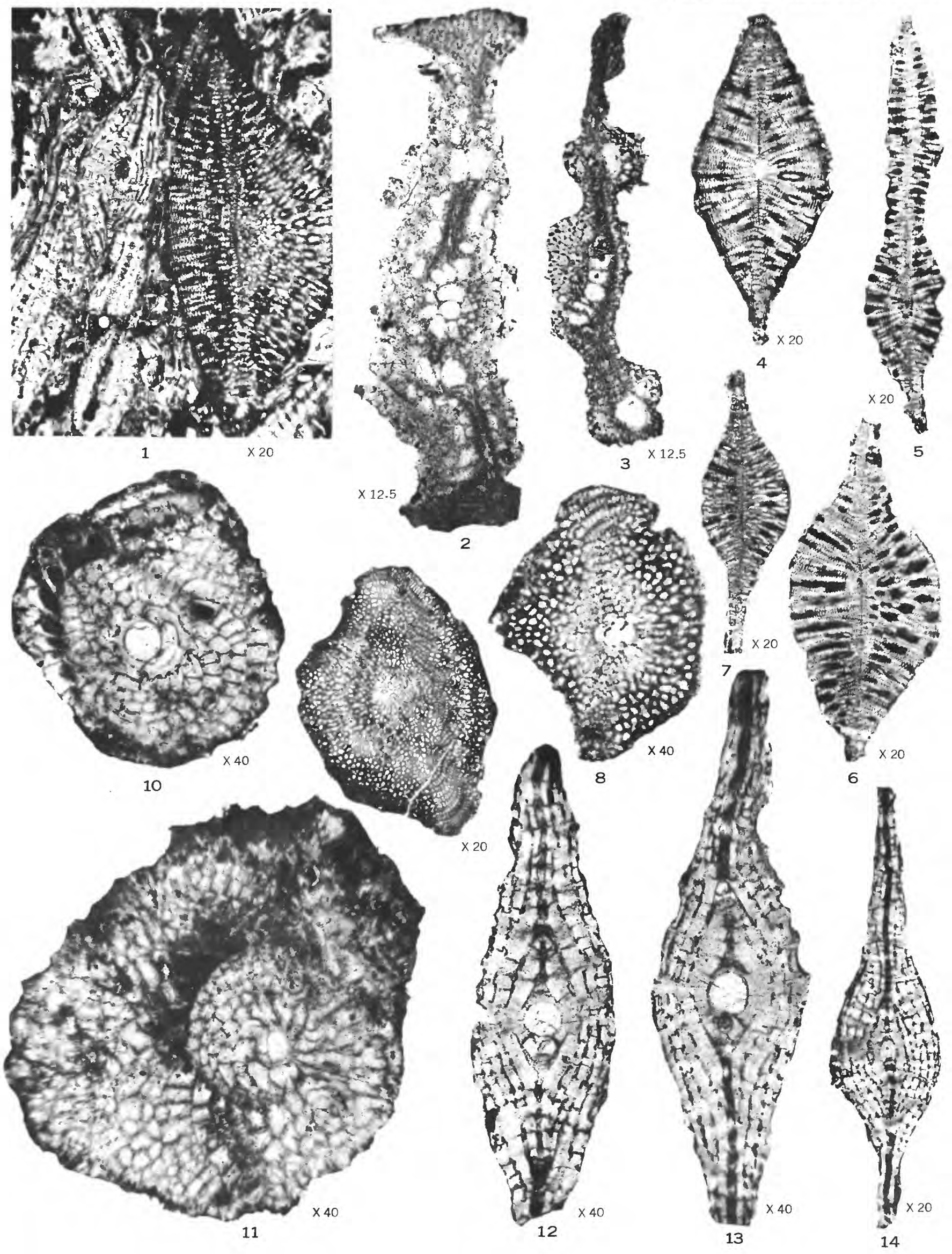

SPIROCLYPEUS, PELLATISPIRA, BIPLANISPIRA, AND ASTEROCYCLINA 

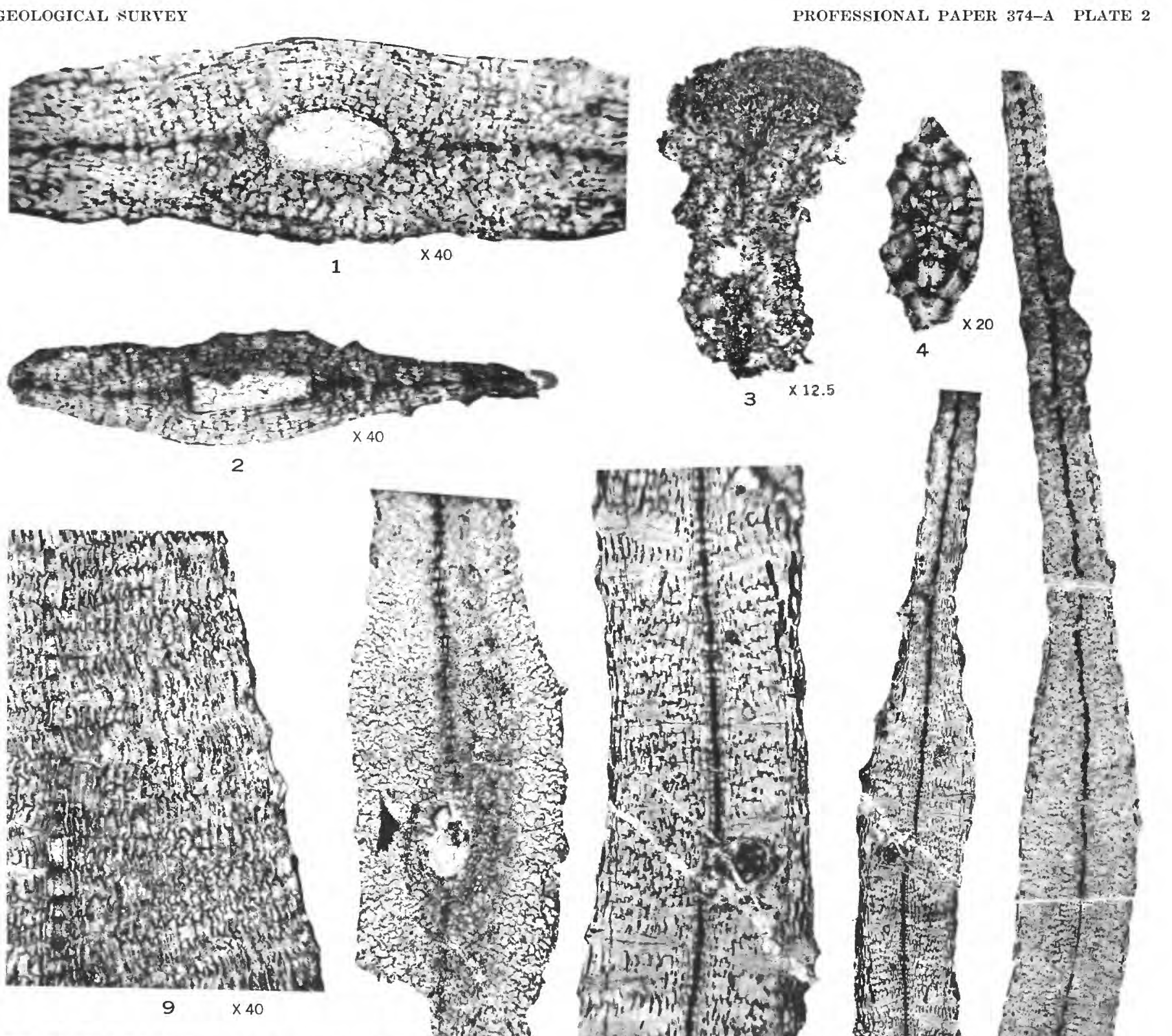

3

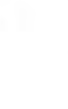

2
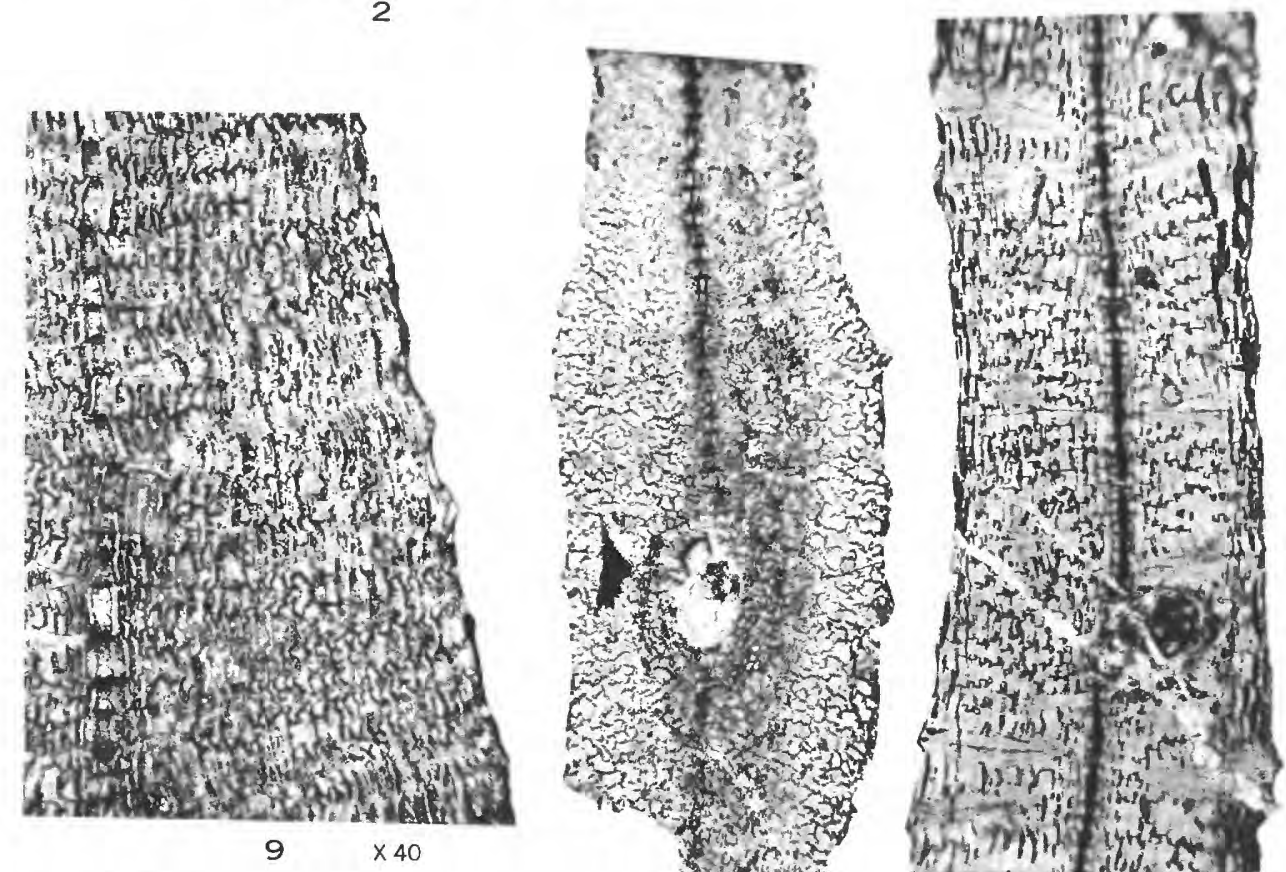

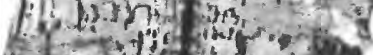

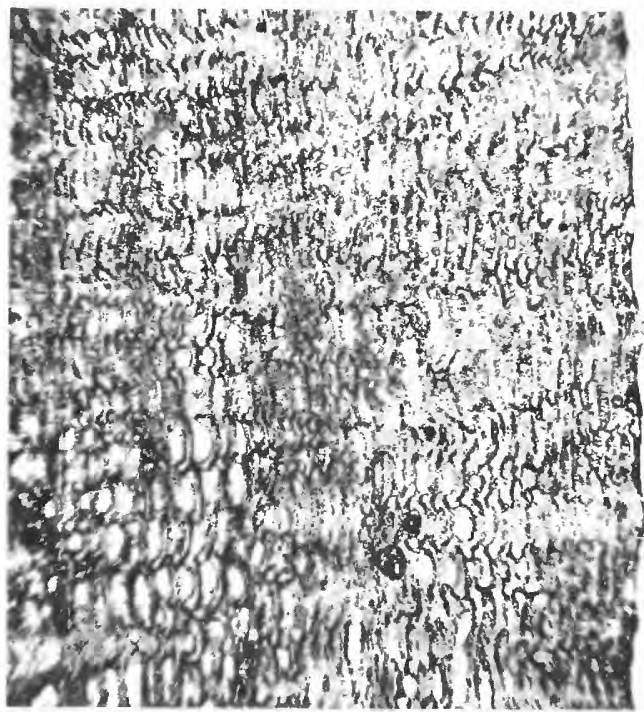

10

$\times 40$
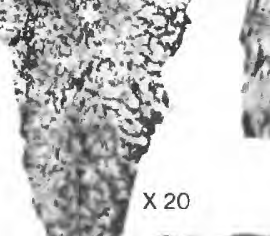

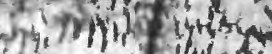
Aving fithe

7

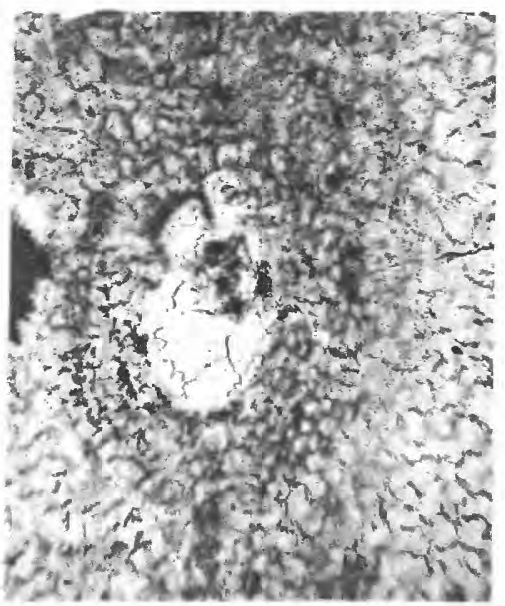

11

$\times 40$

at

g.
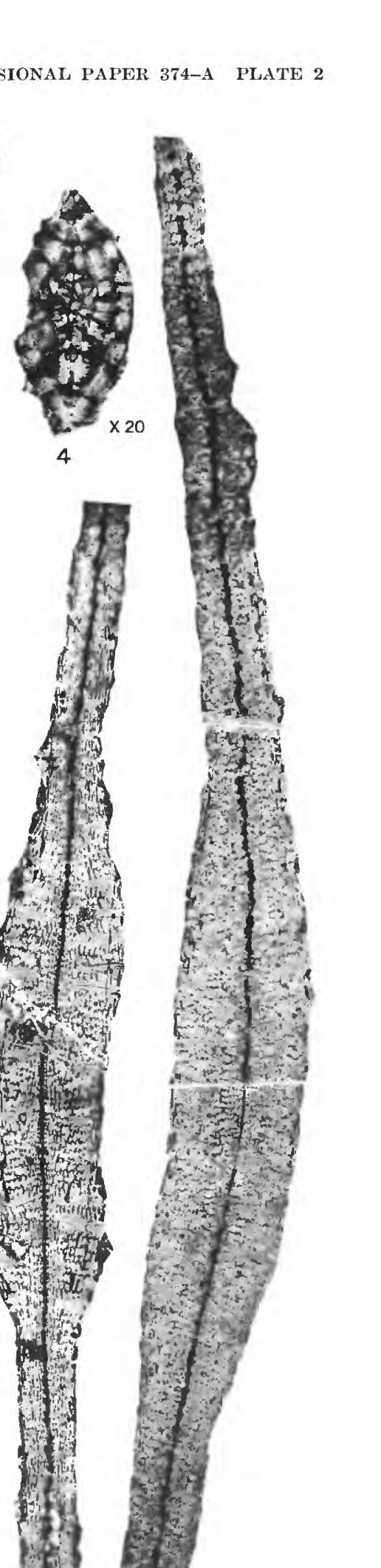

12.

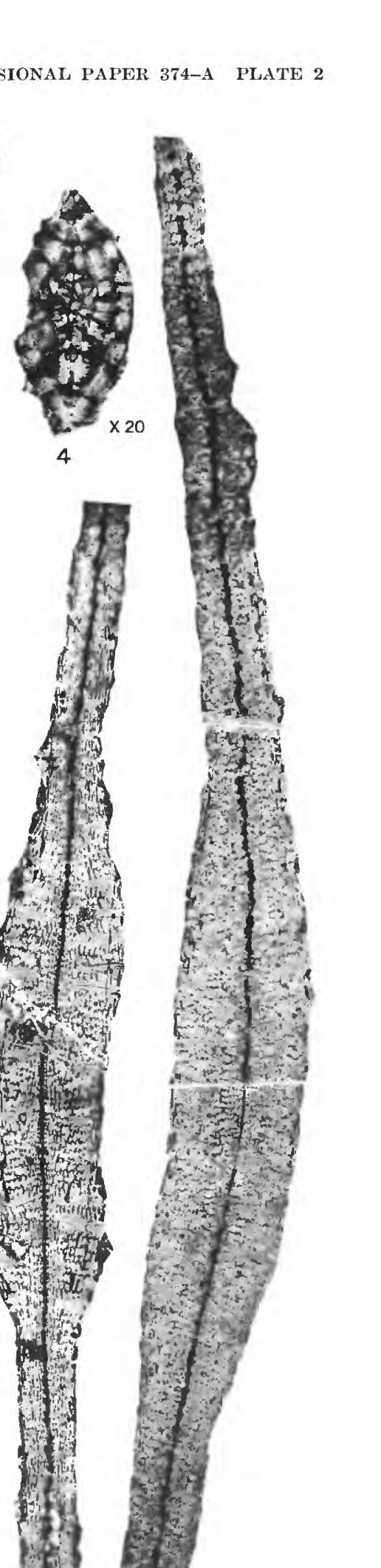

sis
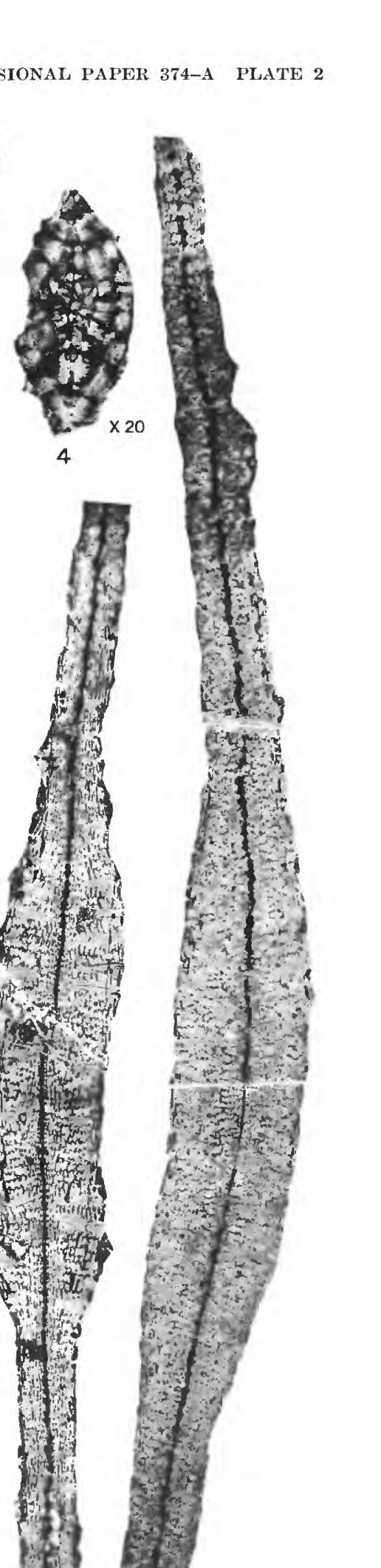

Af Mis 18 tit

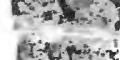
3) It as

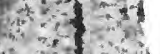

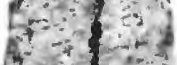
t. $3 x^{2}$ th st. $-4, x=1$ - $4 \times 1 ;: 3$ $-10512 \times$ fint ${ }^{4}$ $-x+2+2$ $-x$ $x^{2}+1$

3

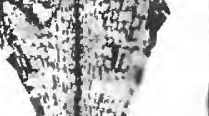

ntury

ist

(4)

to

th

4

sto

tit.

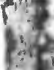

(2)

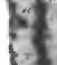

,
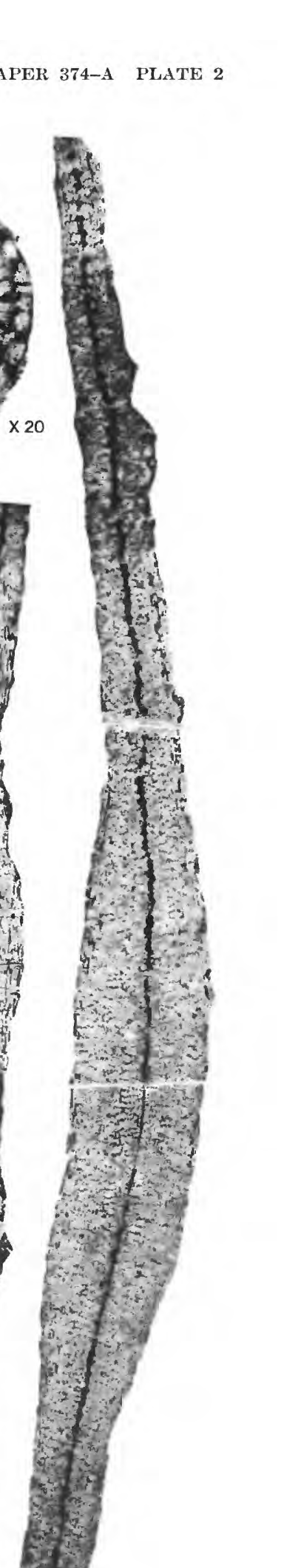

. 

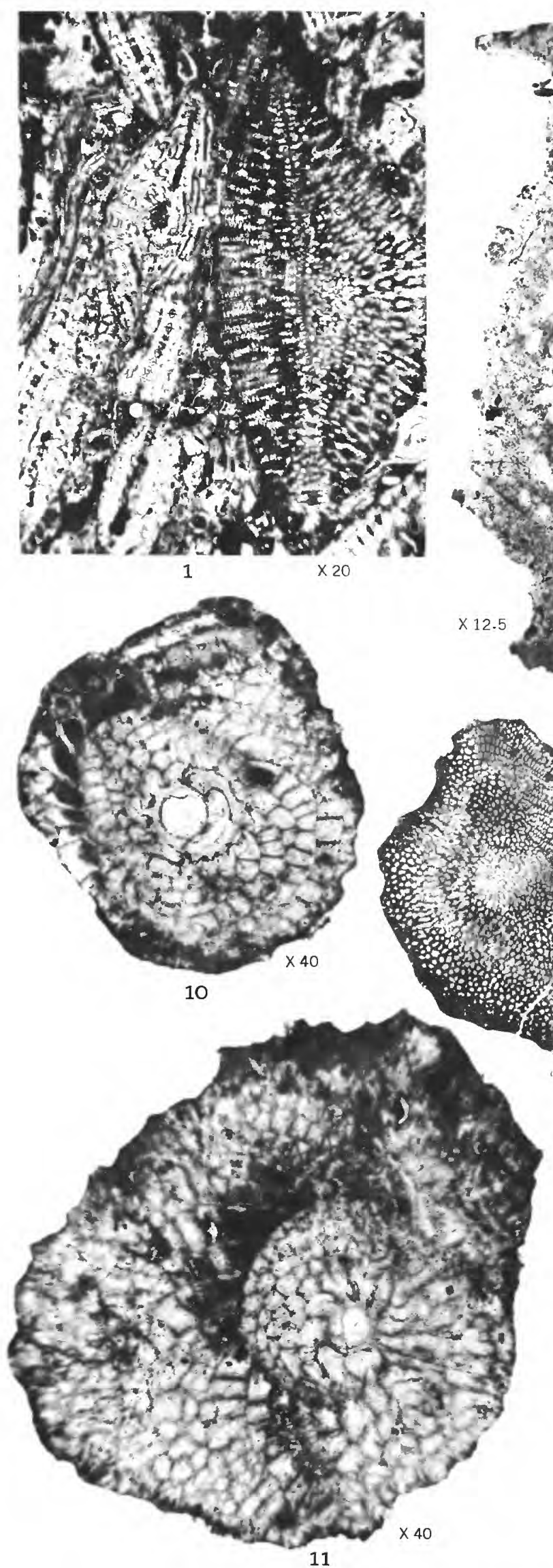
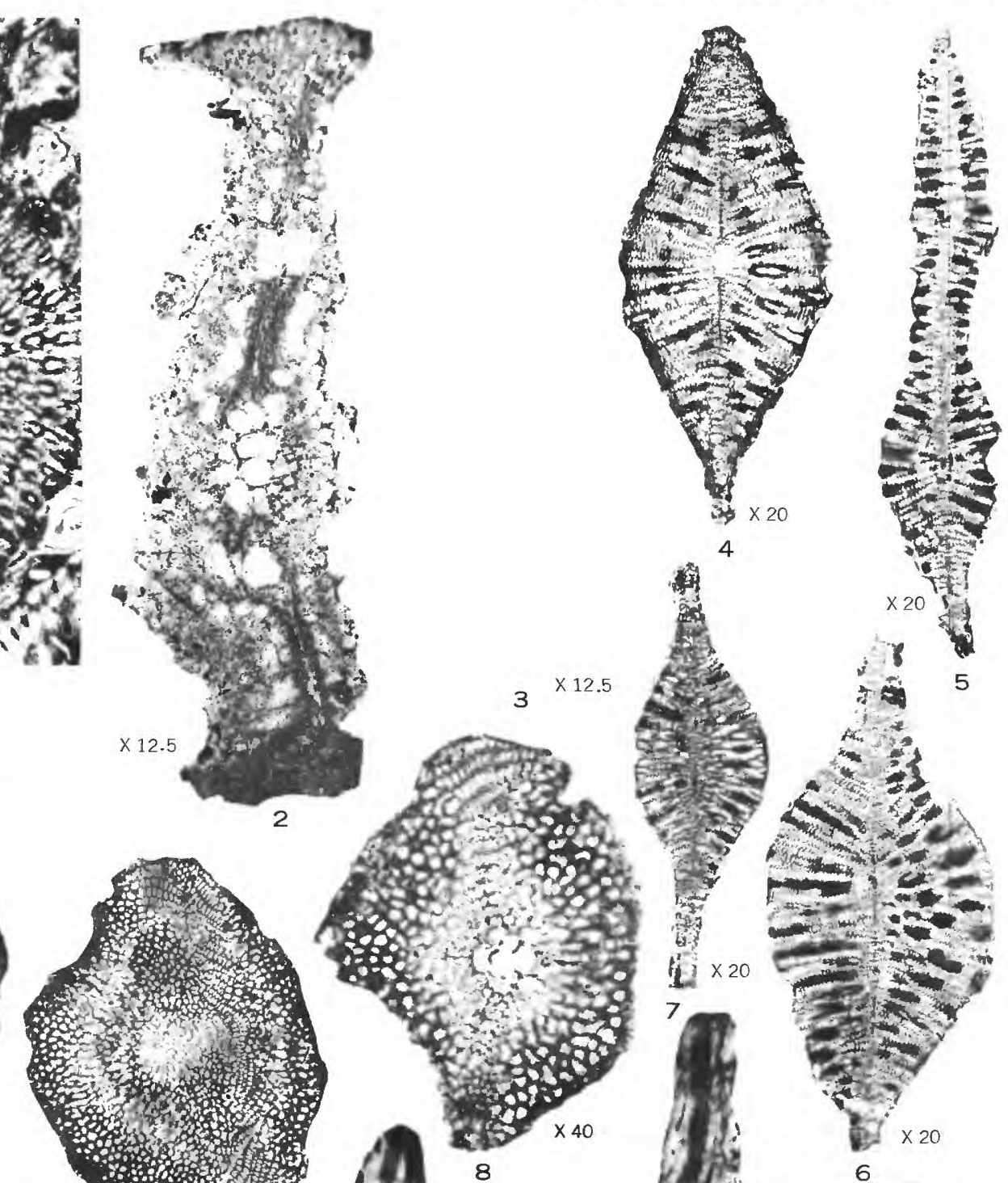

承
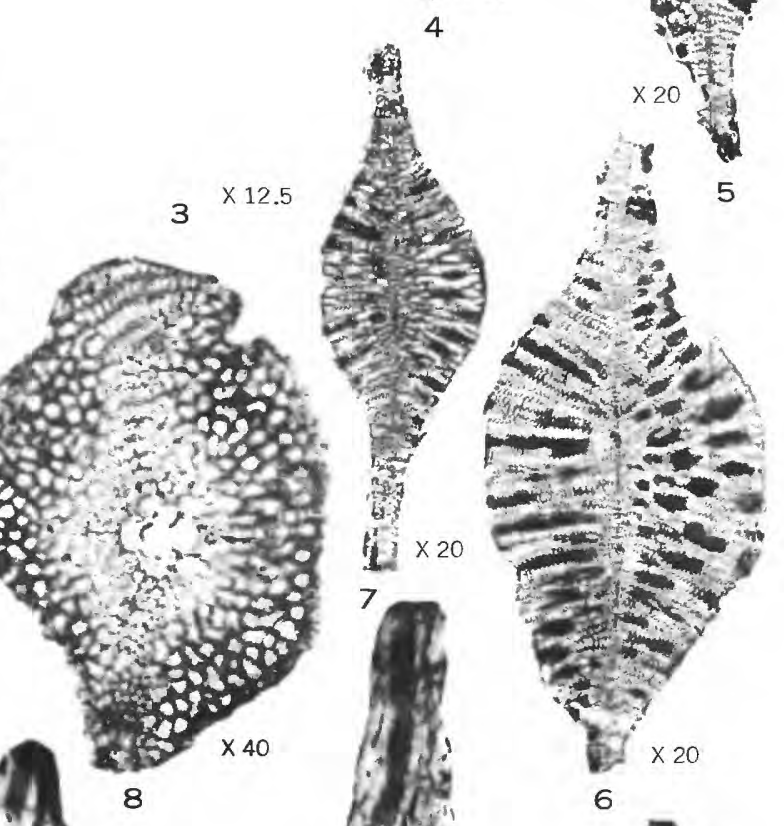
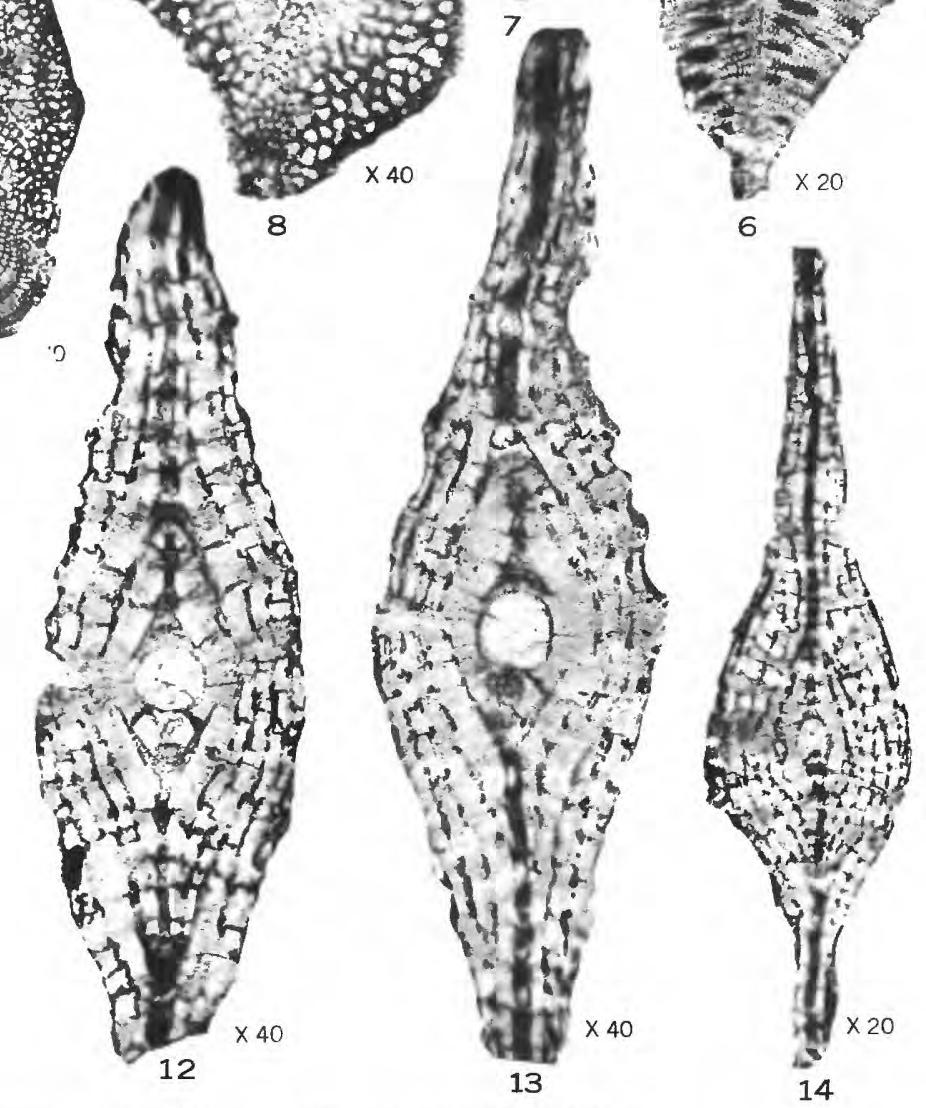

SPIROCLYPEUS, PELLATISPIRA, BIPLANISPIRA, AND ASTEROCYCLINA 

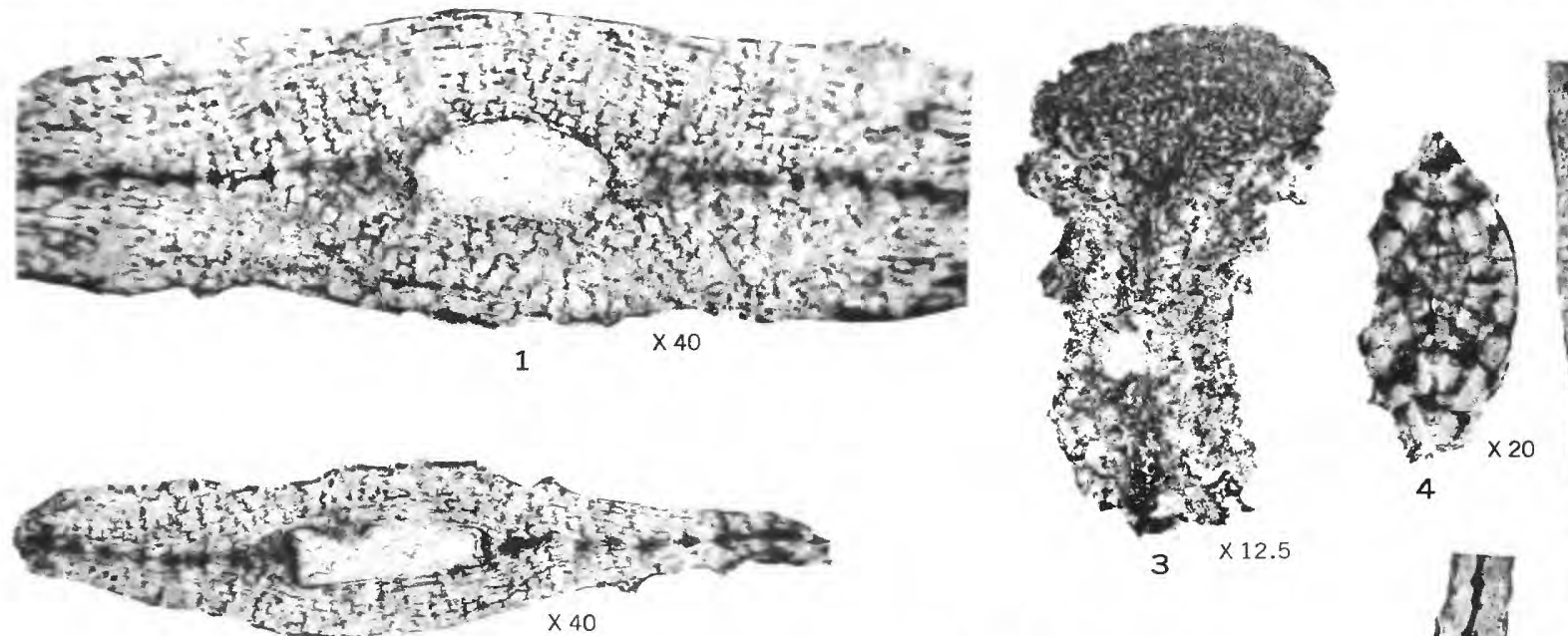

2

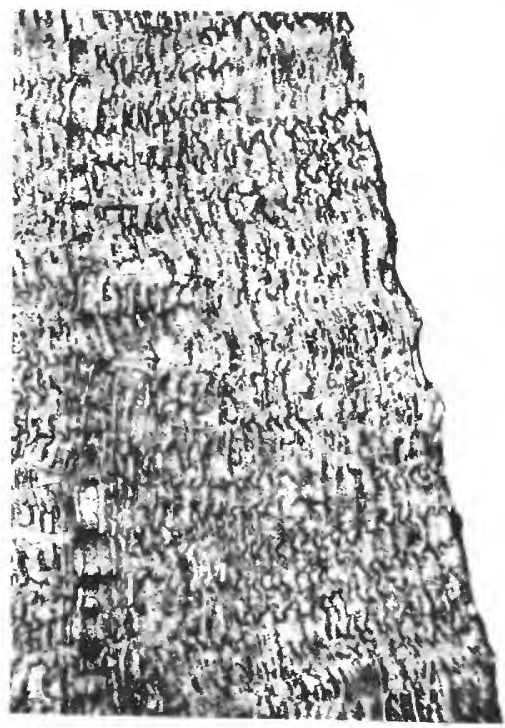

9

$\times 40$

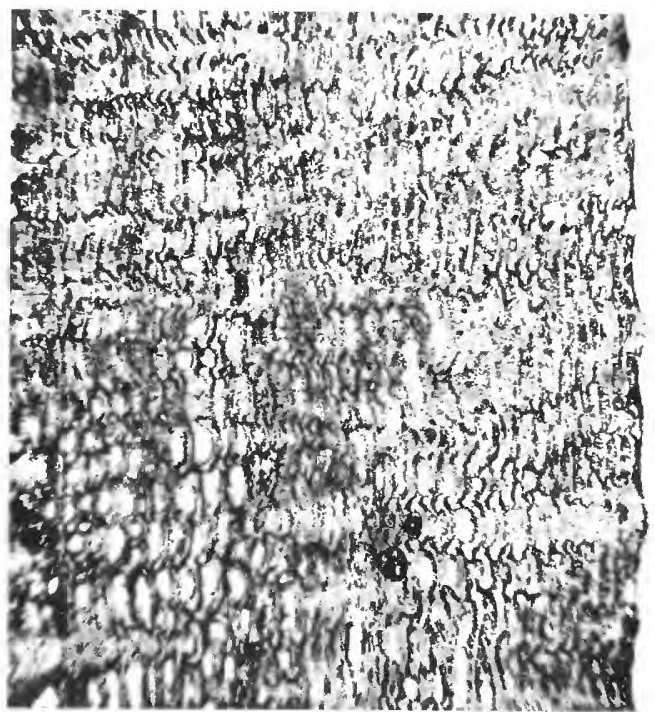

10

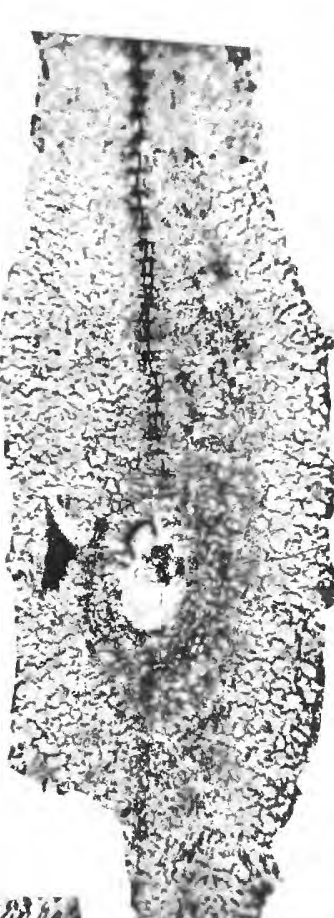

sitiog
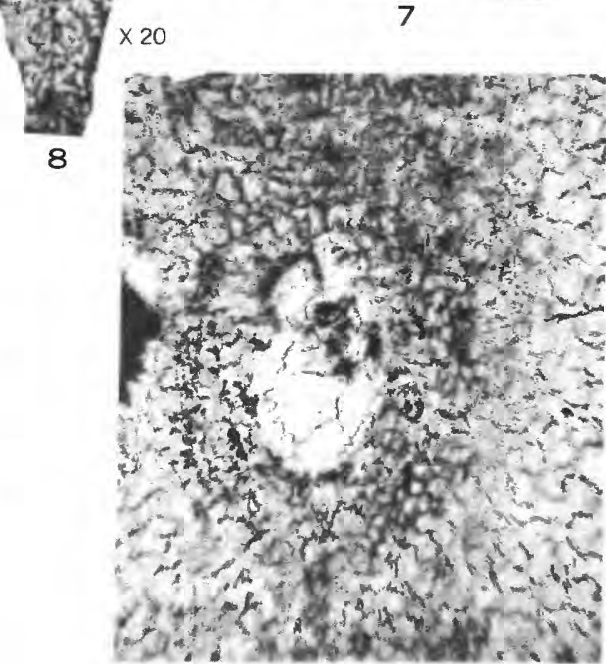

11
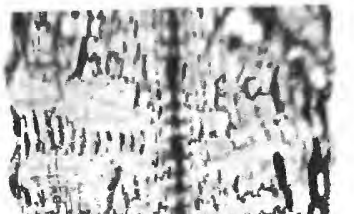

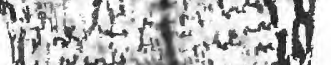

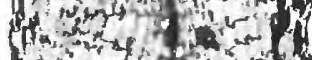
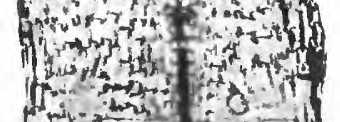

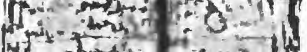

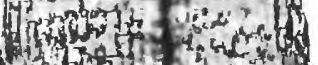

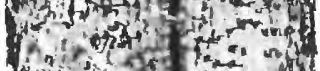

(it)

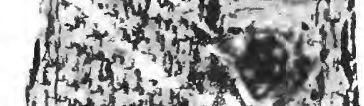

(i)

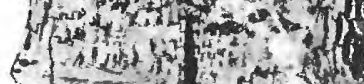

I.

I.

wividith
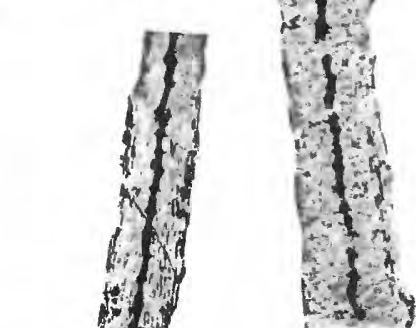

Hon

15

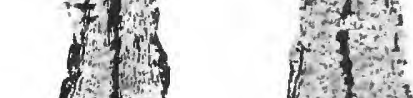

(a)
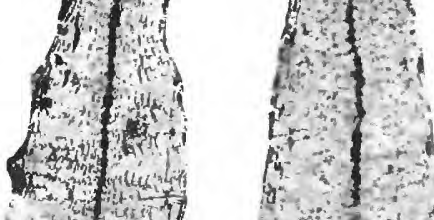

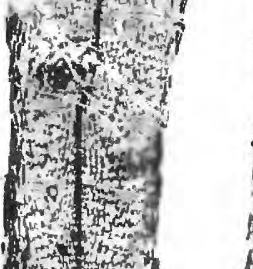

if

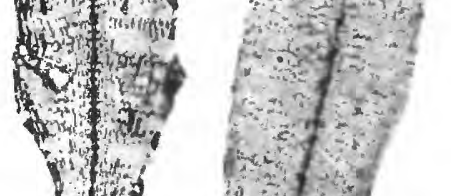

$=7 x+3$

$\sec { }^{2}{ }^{2}$

retris

$-1$

int?
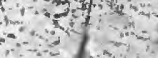

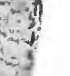




\section{PLATE 2}

FiguRes 1, 2, 5-11. Discocyclina (Discocyclina) omphala (Fritsch) (p. A-5)

1, 2. Parts of vertical sections of megalospheric individuals; locality 3. USNM 627586.

5. Vertical section, not centered, of an umbonate specimen; locality 3 . USNM 627587 .

6. Vertical section, not centered, of a specimen with a depressed central zone; locality 3 . USNM 627588

7. Enlarged part of the central area of the specimen illustrated as fig. 6 to show the details of the internal structures.

8. Oblique equatorial section of a megalospheric individual; locality 3. USNM 627589.

9, 10. Parts of a vertical section of a specimen from the Vaughan Indonesian collection identified as Discocyclina (Discocyclina) javana (Verbeek) to show the variable character of the lateral chambers; precise locality in Indonesia unknown. USN M 627590.

11. Enlarged part of the central area of the specimen illustrated as fig. 8 .

3. Biplanispira fulgeria (Whipple) (p. A-5) Part of a transverse section to show the expanded marginal cord; locality 1. USNM 627591 .

4. Camerina pengaronensis (Verbeek) (p. A-4)

Transverse section, not centered; locality 1. USN M 627592. 


\section{PLATE 3}

Figures 1, 2, 6, 8. Heterosiegina sp. (p. A-4)

1, 2. Median sections; locality 4. USNM 627567.

6, 8. Transverse sections; locality 4. USNM 627568.

3, 4, 7. Gypsina discus Goës (p. A-5)

3. Vertical section, near center; locality 4. USNM 627569.

4. Equatorial section to show the embryonic and equatorial chambers; locality 4. USN M 627570.

7. The same specimen as figure 3, enlarged to show the details of the equatorial layer and the lateral chambers.

5, 9-18. Camerina fichteli (Michelotti) (p. A-4)

$5,9,10,14,15,17,18$. Transverse sections to show variation between specimens; 17 , the same specimen as figure 5, enlarged; locality 4. USNM 627571 .

11. Section parallel to, but above, the median plane to illustrate the reticulate pattern; locality 4 . USNM 627572 .

12. Slightly oblique median section to illustrate the reticulate pattern and shape of the chambers of the median plane; locality 4. USNM 627573.

13. Median section of a small specimen showing the embryonic chambers; locality 4. USNM 627574 .

16. Strongly oblique median section which shows the chambers of the median plane only in the upper part; locality 4. USNM 627575. 

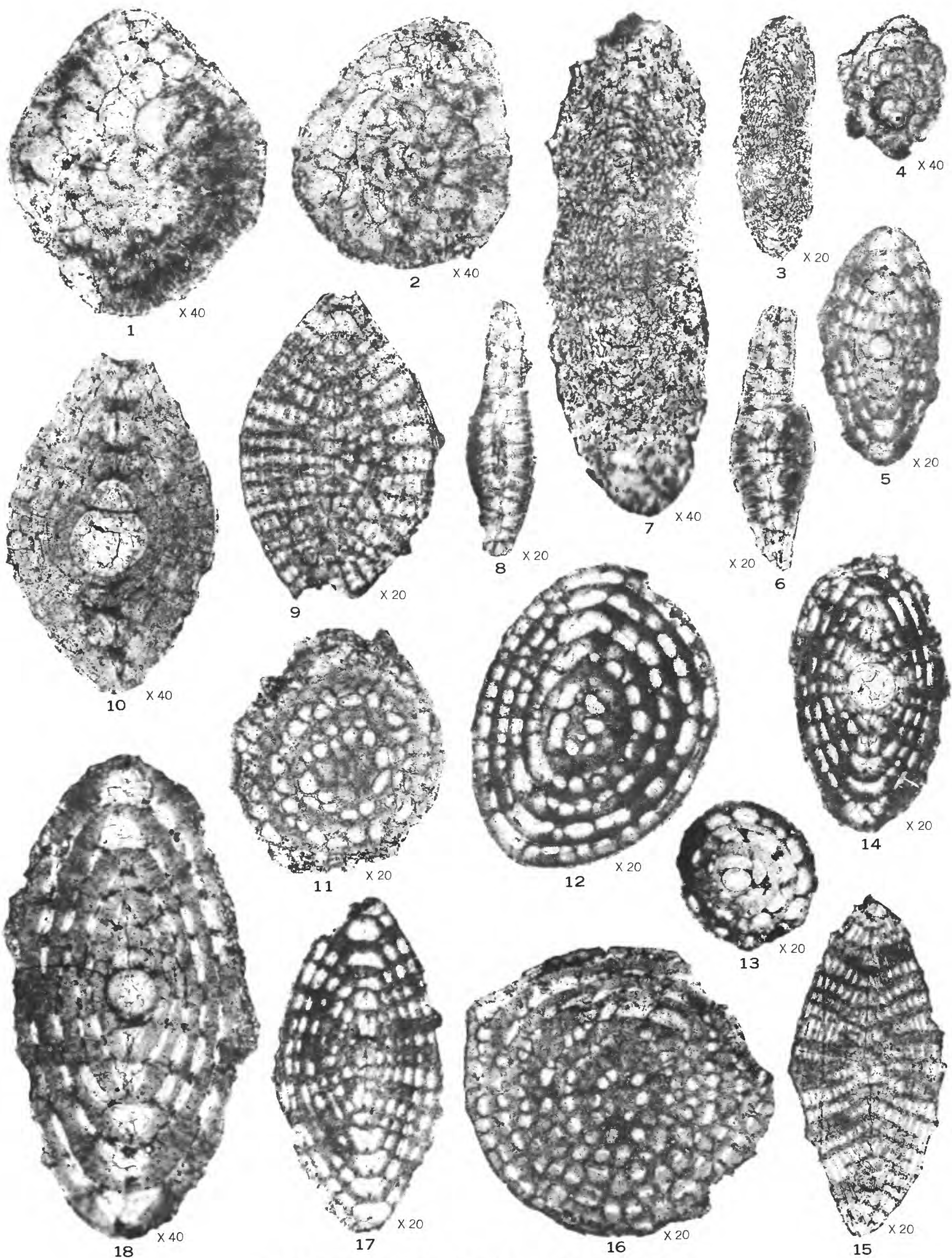

HETEROSTEGINA, GYPSINA, AND CAMERINA 
